\title{
PALEOBIOGEOGRAPHY OF MESOZOIC ARTICULATE BRACHIOPODS FROM THE WESTERN CORDILLERA OF NORTH AMERICA AND THEIR POTENTIAL FOR PALEOGEOGRAPHIC STUDIES
}

\author{
SANDY, Michael R., Dept. of Geology, University of Dayton, 300 College Park, \\ Dayton, OH 45469-2364, U.S.A.
}

Mesozoic brachiopods were, at times, significant elements of marine invertebrate faunas. Current investigations suggest that Mesozoic brachiopods are more common in Mesozoic marine sequences from North America than has generally been assumed. Their neglect is no doubt in part due to the greater utility of other invertebrate and microfossil groups for biostratigraphy. Brachiopods may be preserved in original shell material or silicified. It is therefore necessary to consider which is the most appropriate method of extraction, depending on type of preservation.

Lacking planktotrophic larval stages, living articulate brachiopods are limited in their dispersal potential by virtue of their sessile, benthic mode of life. If, in addition, all post-Paleozoic articulate brachiopods possessed a non-planktotrophic larval stage endemism would be likely to develop if gene-flow became severed. This would mean that taxonomic investigation of articulate brachiopods has the potential to provide useful paleobiogeographic and paleogeographic information. Recent investigations have concentrated on making a preliminary survey of some brachiopod occurrences in the Western Cordillera of North America with these goals in mind.

The Upper Triassic brachiopod fauna from the Luning Formation of the Pilot and Shoshone Mountains, Nevada, is the most diverse known for the Mesozoic of North America in terms of number of brachiopod species (manuscript submitted with George D. Stanley). This is probably a reflection of how little detailed collecting and systematic study Mesozoic representatives of the phylum have received in North America. The fauna comprises both Tethyan and endemic species. The brachiopods are from the Paradise terrane, probably close to the North American craton in the Late Triassic. One Upper Triassic brachiopod fauna from the Antimonio Formation, Sonora, is by comparison with the Nevada faunas, depauperate, but they do share one common species. Additional time-equivalent brachiopod faunas from outboard terranes of North America and the "classic" European faunas monographed in the nineteenth and early twentieth centuries require investigation to determine their paleobiogeography and their contribution to paleogeography.

Jurassic brachiopods from North America have not been subjected to any major revision but they are present at certain horizons. Cretaceous faunas from the southern United States and Mexico contain genera known from Tethys in Europe. Mid-Cretaceous faunas from the Queen Charlotte Islands (Wrangellia terrane) and the Canadian Arctic Islands contain forms that are more typical of mid-latitude to Boreal regions, repectively, of Europe. This suggests a broad correspondence between brachiopod distributions and paleolatitude across considerable paleolongitudinal distances, an observation of relevance to interpreting Early Mesozoic paleobiogeographic distributions.

The current work is only scratching the surface of the Phylum's distribution in the Western Cordillera of North America. The aim is to provide a better understanding of brachiopod paleobiogeography, paleogeography, and the evolutionary history of the Brachiopoda during the post-Paleozoic, which does not appear to be their swansong. 